\title{
ENVIRONMENTAL NOISE AND ANNOYANCE IN ADULT POPULATION OF SKOPJE: A CROSS- SECTIONAL STUDY
}

\author{
Gordana RISTOVSKA, Dragan GJORGJEV, Aziz POLOZHANI, Mihail KOČUBOVSKI, \\ and Vladimir KENDROVSKI
}

Institute of Public Health, Medical Faculty, University Sts. Cyril and Methodius, Skopje, Macedonia

Received in February 2009

Accepted in July 2009

\begin{abstract}
The aim of this study was to identify noise exposure indicators during day and night in the city of Skopje and to see if there is an association between these noise exposure indicators and annoyance. We have performed noise measurements and interviewed 510 adult subjects, using a questionnaire, prepared according to the ISO/TS-15666 standard. Average noise level over the day $\left(\mathrm{L}_{\text {day }}\right)$ was $(62 \pm 6.45) \mathrm{dB}(\mathrm{A})$ and over night $\left(\mathrm{L}_{\text {night }}\right)(56 \pm 6.52) \mathrm{dB}(\mathrm{A})$. Thirteen percent of subjects reported a high level, and $33.5 \%$ moderate level of annoyance. The most annoying noise sources were construction activities (34\% of the subjects), road traffic $(24 \%)$, and leisure/entertainment activities $(18 \%)$. We found a significant association between exposure to $\mathrm{L}_{\mathrm{day}}$ in the range $61 \mathrm{~dB}(\mathrm{~A})$ to $65 \mathrm{~dB}(\mathrm{~A})$ and annoyance in the exposed population (chi-square $=86.14 ; \mathrm{p}<0.001$; Spearman's $\mathrm{R}=0.45 ; \mathrm{p}<0.05)$. During the night time annoyance was reported with exposure to $\mathrm{L}_{\text {night }}$ above $46 \mathrm{~dB}(\mathrm{~A})$. Levels of annoyance in Macedonia are similar to levels in developed European countries. Differences are in the source of noise. This study has shown that environmental noise is a significant hazard in urban environments, and assessment of annoyance may prove a useful tool for town planners and public health policy makers.
\end{abstract}

KEY WORDS: construction, daytime noise, exposure assessment, night time noise, public health, road traffic, town planning

About $40 \%$ of population in the European Union is exposed to road traffic noise levels exceeding $55 \mathrm{~dB}(\mathrm{~A})$ during daytime, and $20 \%$ are exposed to levels exceeding $65 \mathrm{~dB}(\mathrm{~A})$. At night more than $30 \%$ are exposed to an equivalent level exceeding $55 \mathrm{~dB}(\mathrm{~A})$. Community noise is a growing hazard in developed and developing countries and is accompanied by an increasing number of complaints from the exposed people (1). Stress can be seen as an effect of or as a coping (fight/flight) reaction of the body, that is, a physiological reflex to noise (2). There are several modes of this reaction, based on the general stress concept. Community noise causes considerable disturbance and annoyance in exposed population. Beside psychosocial effects of community noise, there is concern about the impact of noise on public health, particularly regarding cardiovascular outcomes (3).

One of the models for noise and health (Dutch Health Council) assumes that health effects are determined by a combination of endogenous and exogenous factors such as physical and social environment and lifestyle. Noise exposure is only one of these exogenous factors. This process may be modified by personal characteristics such as attitude and coping strategies. According to this model, noise exposure can induce biochemical, physiological or psychosocial changes such as annoyance, sleep disturbance, performance, 
concentration. Annoyance and vegetative responses lead to somatic and psychosomatic responses such as blood dynamics, hormone and lipoprotein levels, and cardiovascular and psychiatric disorders (2).

The effects of community noise can be evaluated by assessing the extent of annoyance in exposed population. Annoyance is defined as a feeling of displeasure associated with an agent or condition, known or believed by an individual or a group to adversely affect them. Many studies have shown that equal levels of traffic and industrial noise results in different magnitudes of annoyance (4). According to the curves synthesised by Schultz and Miedema $(1,4)$ the percentage of people highly or moderately annoyed was related to the day and night continuous equivalent sound level $\left(\mathrm{L}_{\mathrm{dn}}\right)$. High annoyance in a population started at the $\mathrm{L}_{\mathrm{dn}}$ of $42 \mathrm{~dB}(\mathrm{~A})$ and moderate annoyance at $37 \mathrm{~dB}(\mathrm{~A})$. Annoyance in population exposed to environmental noise varied not only with the acoustical characteristics of the noise, but also with many nonacoustical factors such as social, psychological, or economic background, or the conviction that noise could be reduced $(1,4,5)$. The correlation between noise exposure and general annoyance is much higher at the group level than at individual level. Data from 42 surveys have shown that about $70 \%$ of the variety of annoyance at the group level is explained by noise exposure characteristics (5).

Skopje, the capital of Macedonia, has become a typical urban centre, and a referent example for urban noise pollution. Measurements of environmental noise in Skopje have shown that the noise level in the main streets varies between $72 \mathrm{~dB}(\mathrm{~A})$ and $78 \mathrm{~dB}(\mathrm{~A})$, and that noise level depends on traffic flow and town planning $(7,8)$.

The aim of this study was to identify noise indicators for exposure in the daytime and night time, $\mathrm{L}_{\text {day }}$ and $\mathrm{L}_{\text {night }}$, respectively, in the city of Skopje, and to determine the relationship between noise exposure indicators and annoyance in exposed population.

\section{METHODS}

\section{Sample}

Study subjects were randomly selected from population living in different locations of Skopje: in the city centre, in nearby streets with heavy traffic (Madžari), in mixed residential / administrative / market areas (Aerodrom, Čair), and in a suburban area where we expected low noise levels (Gjorče Petrov). The subjects were randomised as follows: first we selected buildings, then every third flat in the building, and finally one member of family who agreed to participate. Inclusion criteria were age between 18 and 65 years and at least one year of residence at the current address. Seven hundred residents were contacted to be interviewed for assessment of noise annoyance, and 510 responded. The questionnaire was developed according to the ISO/TS-15666 (8) using a five-item verbal scale and a eleven point numerical scale. The subjects answered questions related to the extent of annoyance with different noise sources over the last 12 months when being at home. The five-item verbal scale used the verbs "not annoyed, very little annoyed, moderately annoyed, highly annoyed, and very highly annoyed". Answers "highly annoyed" and "very highly annoyed" were treated as high level of annoyance, and answers "not annoyed" and "very little annoyed" as not annoyed. On the numerical scale, 0 was equivalent to "not annoyed at all" and 10 was equivalent to "extremely annoyed". Values from 0 to 4 meant not annoyed, 5 to 7 moderately annoyed, and 8 to 10 highly annoyed.

\section{Noise measurements}

We choose $\mathrm{L}_{\text {day }}$ and $\mathrm{L}_{\text {night }}$ as noise exposure indicators for urban population. $\mathrm{L}_{\text {day }}$ presents longterm exposure to average equivalent energy noise level during the day from 07:00 $\mathrm{h}$ to $23: 00 \mathrm{~h}$. $\mathrm{L}_{\text {night }}$ presents long-term exposure to average equivalent energy noise level during the night from 23:00 $\mathrm{h}$ to 07:00 h. Measurement points were located in the city centre, which is a residential/administrative/market area with intense traffic and various activities, and in entirely residential suburbia with the aim to cover different noise levels. Community noise was measured with a Brüel \& Kjaer 2260 Investigator type sound analyser for one week in the spring and one week in the autumn of 2006. Measurements were taken at 15 minute intervals for the day time $(07: 00 \mathrm{~h}$ to $23: 00 \mathrm{~h}$, $\mathrm{L}_{\text {day }}$ ) and two measurements were taken for the night time (23:00 h to 07:00 h; $\left.\mathrm{L}_{\text {night }}\right)$.

\section{Statistical analysis}

We used Statistica version 7.1 and SPSS version 13.0 to determine the mean, standard deviation, and $95.0 \%$ confidence intervals for numeric data series. We used the chi-square test to test the association 
between parameters and Spearman's rank order correlations to see if there was a correlation between exposure indicators and annoyance (10).

\section{RESULTS}

The total number of subjects was 510, 243 (47.65\%) were men and $267(52.35 \%)$ women. Their mean age was $(37.34 \pm 14.38)$ years.

After determination of noise exposure indicators (Table 1), we divided the subjects in four groups according to the $\mathrm{L}_{\text {day }}$ value and residence. Most subjects, $160(31.4 \%)$ of them, were exposed to $\mathrm{L}_{\text {day }}>65 \mathrm{~dB}(\mathrm{~A}), 126(24.7 \%)$ were exposed to $\mathrm{L}_{\text {day }}$ in the range between $61 \mathrm{~dB}(\mathrm{~A})$ and $65 \mathrm{~dB}(\mathrm{~A}), 151$ $(29.6 \%)$ to noise from $56 \mathrm{~dB}(\mathrm{~A})$ to $60 \mathrm{~dB}(\mathrm{~A})$, and $73(14.3 \%)$ to noise level below $55 \mathrm{~dB}(\mathrm{~A})$, which is the WHO annoyance cut-off point for daytime noise (1) (Table 2). According to the value of $\mathrm{L}_{\text {night }}$, the subjects were also divided in four groups, only 18 (3.5\%) subjects were exposed to $\mathrm{L}_{\text {night }}<45 \mathrm{~dB}(\mathrm{~A})$ which is the WHO annoyance cut-off point for night time noise (1); $115(22.5 \%)$ were exposed to $\mathrm{L}_{\text {nigh }}$ in the range of $46 \mathrm{~dB}(\mathrm{~A})$ to $50 \mathrm{~dB}(\mathrm{~A}), 146(28 \%)$ to between $51 \mathrm{~dB}(\mathrm{~A})$ and $55 \mathrm{~dB}(\mathrm{~A})$, and $231(45 \%)$ to $\geq 56 \mathrm{~dB}(\mathrm{~A})$ (Table 2).

Table 1 Noise exposure indicators $L_{d a y}$ and $L_{\text {night }}$

\begin{tabular}{lcc}
\hline $\begin{array}{l}\text { Noise exposure } \\
\text { indicator }\end{array}$ & Mean \pm SD & 95 \% CI \\
\hline $\mathrm{L}_{\text {day }} / \mathrm{dB}(\mathrm{A})$ & $62.43 \pm 6.45$ & 61.87 to 62.99 \\
$\mathrm{~L}_{\text {night }} / \mathrm{dB}$ (A) & $55.57 \pm 6.52$ & 55.01 to 56.14 \\
\hline
\end{tabular}

$S D$ - standard deviation; $C I$ - confidence interval
Analysis of annoyance in the total sample, measured on the scale from 0 to 10 , showed that $13 \%$ of the subjects were highly annoyed with noise, $33.5 \%$ moderately and $53 \%$ not at all. This means that nearly a half of all subjects were annoyed with noise.

According to the five-item verbal scale and to noise source, the most annoying was the noise from construction activities ( $34 \%$ of the subjects), followed by highly annoying road traffic noise ( $24 \%$ of the subjects), leisure activities (various entertainment activities in public places) (18\%), and finally by noise from restaurants and cafeterias (17\%). Neighbourhood noise was the reason for high annoyance in $14 \%$ of the subjects. Railway and aircraft traffic noise seem not to annoy the subjects at all (Figure 1).

We tested the association and correlations between exposure to different noise levels and annoyance in the subject population. We found a significant association between exposure to $\mathrm{L}_{\text {day }}$ in the range of $61 \mathrm{~dB}(\mathrm{~A})$ to $65 \mathrm{~dB}(\mathrm{~A})$ and annoyance (chi-square 86.14; $\mathrm{p}<0.001$ ). The correlation between $\mathrm{L}_{\text {day }}$ and annoyance was positive to moderately strong and significant for levels $\leq 55 \mathrm{~dB}(\mathrm{~A})$ and $61 \mathrm{~dB}(\mathrm{~A})$ to $65 \mathrm{~dB}(\mathrm{~A})$. This suggests that annoyance increases with the increasing trend of daytime noise (Figures 2 and 3). We also found that association between $\mathrm{L}_{\text {night }}$ and annoyance started at levels above $46 \mathrm{~dB}(\mathrm{~A})$ (Table 2).

\section{DISCUSSION AND CONCLUSION}

With the mean $\mathrm{L}_{\text {day }}$ of $62 \mathrm{~dB}(\mathrm{~A})$, the population of Skopje seems to be exposed to day time noise level above the national limit of $55 \mathrm{~dB}(\mathrm{~A})$ and the

Table 2 Relationship between different $L_{\text {day }}$ and $L_{\text {night }}$ and annoyance

\begin{tabular}{lccccc}
\hline Noise exposure & $\begin{array}{c}\text { Number of } \\
\text { subjects (\%) }\end{array}$ & & & \multicolumn{2}{c}{$\begin{array}{c}\text { Spearman rank order } \\
\text { correlations }\end{array}$} \\
\cline { 3 - 6 } & & Chi-square & $\mathbf{p}$ & $\mathbf{R}$ & $\mathbf{p}$ \\
\hline $\mathrm{L}_{\text {day }} / \mathrm{dB}(\mathrm{A})$ & & & & & \\
$\leq 55$ & $73(14.3)$ & 52.89 & 0.083 & 0.24 & $<\mathbf{0 . 0 5}$ \\
56 to 60 & $151(29.6)$ & 27.56 & 0.932 & 0.05 & $>0.05$ \\
61 to 65 & $126(24.7)$ & 86.14 & $<\mathbf{0 . 0 0 1}$ & $\mathbf{0 . 4 5}$ & $<\mathbf{0 . 0 5}$ \\
$>65$ & $160(31.4)$ & 75.54 & 0.862 & 0.05 & $>0.05$ \\
\hline $\mathrm{L}_{\text {night }} / \mathrm{dB}(\mathrm{A})$ & $18(3.5)$ & 8.55 & 0.128 & -0.031 & $>0.05$ \\
$\leq 45$ & $115(22.5)$ & 58.85 & $\mathbf{0 . 0 2 8}$ & -0.132 & $>0.05$ \\
46 to 50 & $146(28.6)$ & 84.84 & $<\mathbf{0 . 0 0 1}$ & -0.125 & $>0.05$ \\
51 to 55 & $231(45)$ & 169.72 & $\mathbf{0 . 0 0 2}$ & $\mathbf{0 . 0 4}$ & $>0.05$ \\
$\geq 56$ & & & &
\end{tabular}

Bold denotes statistical significance. 


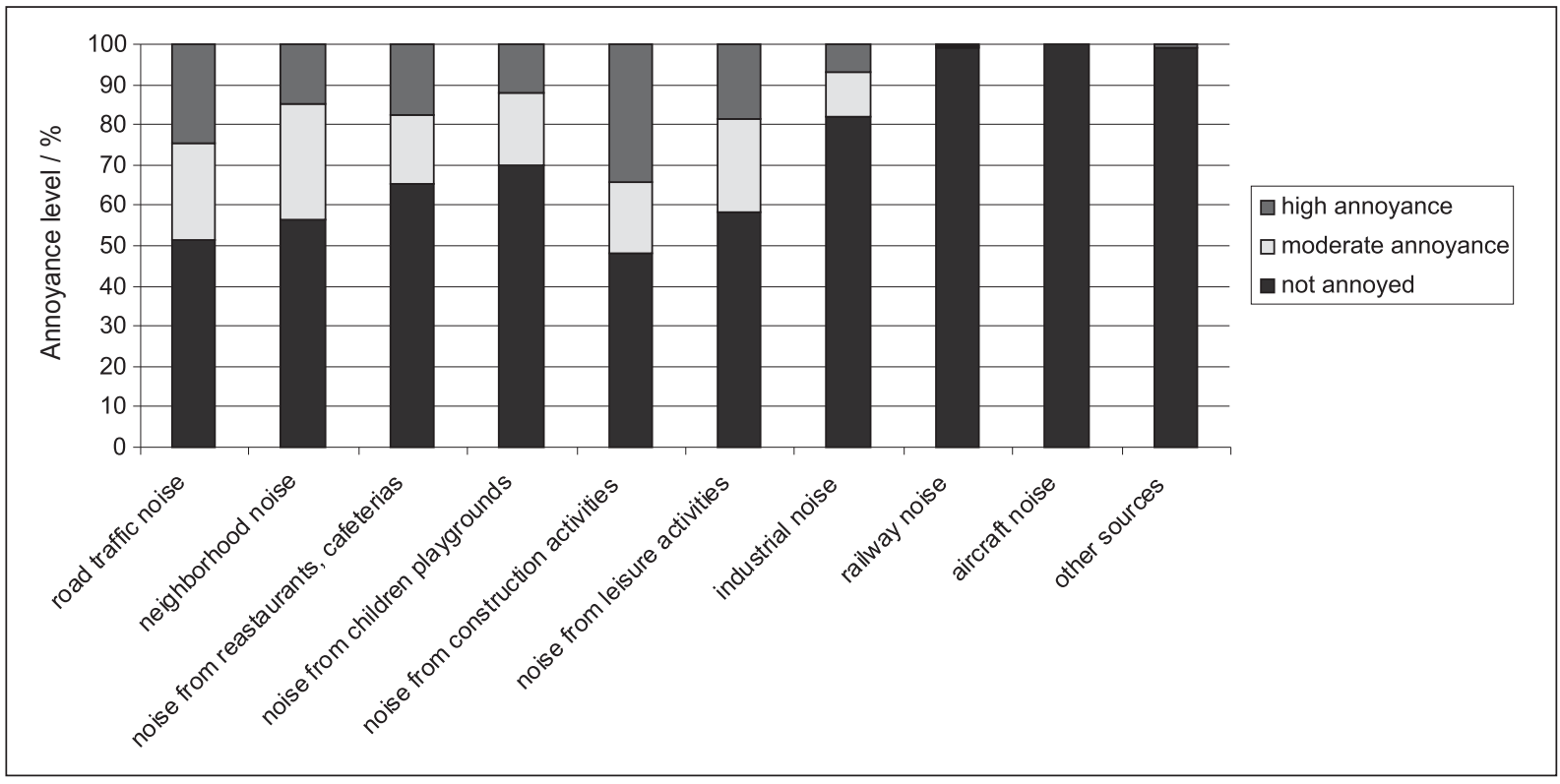

Figure 1 Level of annoyance with noise by sources

WHO recommendation for prevention of annoyance. This is also true for the night time noise, which is $11 \mathrm{~dB}(\mathrm{~A})$ above the national standard for prevention of annoyance and sleep disturbances. We decided to use weighted daytime and night time noise as separate exposure indicators, believing that they may be more appropriate for assessing physiological responses to noise. In urban settings, common daytime noise levels range between $45 \mathrm{~dB}(\mathrm{~A})$ and $75 \mathrm{~dB}(\mathrm{~A})$, and night time average noise levels for road traffic are $7 \mathrm{~dB}(\mathrm{~A})$ to $10 \mathrm{~dB}(\mathrm{~A})$ lower than daytime average, which is relatively independent of street traffic volume (1). $L_{\text {den }}$ is an integrated noise exposure indicator for day time, evening, and night time, which can be weighted or calculated, and has been recommended for use by the EU legislation for environmental noise (11). Penalties of $5 \mathrm{~dB}(\mathrm{~A})$ and $10 \mathrm{~dB}(\mathrm{~A})$ are usually given for evening and night time, respectively. In this context, $\mathrm{L}_{\text {den }}$ appears to be a useful noise indicator for decision-making and regulatory purposes; it can be used for noise mapping, and refers normally to the most exposed facade, which incorporates a certain degree of exposure misclassification regarding causeeffect relationships.

In a review of epidemiological studies of noise effects, Babish (12) relied on daytime $\left(\mathrm{L}_{\text {day }}, 6: 00 \mathrm{~h}\right.$ to 22:00 h) outdoor average A-weighted sound pressure level, which was used in most studies and is more adequate for health-related noise research.

Annoyance analysis has shown that $47 \%$ of the subjects were annoyed with noise to a different degree. This level of annoyance is very similar to other countries, but what makes our study different is the rating of noise sources in terms of annoyance. It turns out that the most annoying source are construction activities, even in suburban areas with low noise level $\left[\mathrm{L}_{\text {day }} \leq 55 \mathrm{~dB}(\mathrm{~A})\right]$, where we found positive and significant correlation between noise level and annoyance $(\mathrm{R}=0.24, \mathrm{p}<0.05)$.

According to results form the WHO Large Analysis and Review of European Housing and Health Status (LARES) project (6) conducted in eight European countries, the most annoying source of noise was traffic, which $14 \%$ of subjects found highly and $38 \%$ moderately annoying. Neighbourhood was the second most annoying source of noise, causing high and moderate level of annoyance in $12 \%$ and $35 \%$ of subjects, respectively.

This argues in favour of field investigation as the most appropriate to assess annoyance with noise. Case-by-case research is the most appropriate way to identify noise sources in a specific environment and non-acoustic factors in community response to noise.

According to dose-response curves bringing together different types of traffic noise and the most annoying is aircraft noise, then road traffic noise, and finally railway noise. Studies have shown that equal traffic noise levels cause different annoyance because of the influence of non-acoustic factors $(4,5)$. The most important non-acoustic factor is individual noise sensitivity, demographic (age, 


\section{$\mathrm{L}_{\text {day }} \leq 55 \mathrm{~dB}(\mathrm{~A}) /$ annoyance $R=0.24(p<0.05)$}
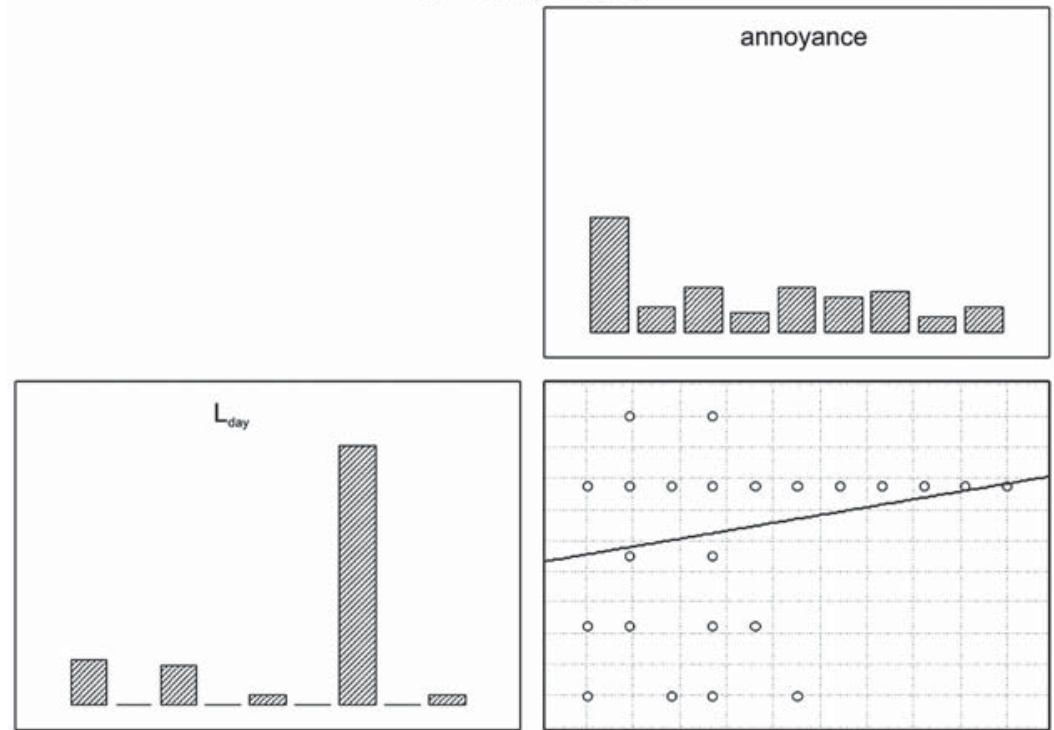

Figure 2 Significant correlation between $L_{d a y} \leq 55 d B(A)$ and annoyance

$$
\begin{gathered}
\mathrm{L}_{\text {day }}=(61 \text { to } 65) \mathrm{dB}(\mathrm{A}) / \text { annoyance } \\
\mathrm{R}=0.45(\mathrm{p}<0.05)
\end{gathered}
$$
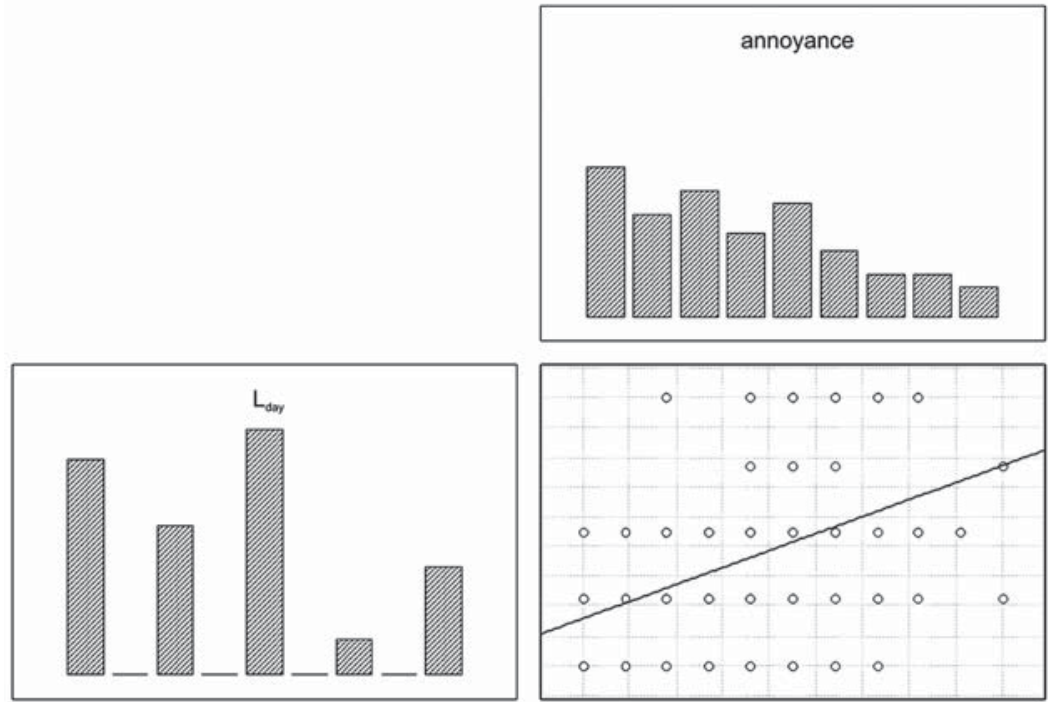

Figure 3 Significant correlation between $L_{d a y}$ in the range of $61 d B(A)$ to $65 d B(A)$ and annoyance

gender), lifestyle, residence time, previous noise experience. Therefore we need to further investigate annoyance with noise to identify additional factors affecting community response to noise. Self-reported annoyance or subjective evaluation of noise response has a much bigger influence on health than objective noise exposure (12). Schulte, von Eiff, Neus, Ruddle (13) have published evidence that hypertension is in correlation with subjective evaluation of noise sensitivity and noise annoyance in noisy and quiet areas. They have found that noise annoyance is in correlation with antihypertensive treatment in areas with moderate exposure to noise, but they didn't find this correlation in areas seriously burdened with traffic noise.

Subjects with manifest health problems may be more likely to give exaggerated answers about their annoyance by traffic noise in the interview, although 
they were not being stressed by the noise. They may tend to blame their environment for their health status, hoping that the results of a study might influence future noise policy. Subjects who believe that noise contributes to their health problem may be more dissatisfied and annoyed with noise (14-17).

In this study, we did not use $\mathrm{L}_{\text {den }}$ as an integrated noise exposure indicator because our primary goal was to make a clear distinction between day and night time noise exposure and to explore their association with annoyance. However, we will use $\mathrm{L}_{\text {den }}$ in future research to establish the dose-response curve.

This is the first national study assessing noiseinduced annoyance in adult population, and it has shown that we have to address environmental noise as a significant hazard in urban environments of Macedonia, paying particular attention to the most annoying sources such as construction industry and road traffic. To prevent adverse health effects, measures to abate night time noise have to be introduced. We also need to continue investigating specific noisy environments. Methods used in this study have proved to be useful tools in assessing noise-induced annoyance.

\section{REFERENCES}

1. Berglund B, Lindvall T, Schwela DH. Guidelines for Community Noise. Geneva: WHO; 1999.

2. van Kempen EEMM, Kruize H, Boshuizen HC, Ameling $\mathrm{CB}$, Staatsen BAM, de Holander AEM. The association between noise exposures and blood pressure and ischemic heart disease: a meta-analysis. Environ Health Perspect 2002;110:307-17.

3. Babish W, Ising H, Gallacher JEJ. Health status as a potential modifier of the relation between noise annoyance and incidence of ischemic heart disease. Occup Environ Med 2003;60:739-45.

4. Miedema HM. Relationship between exposure to multiple noise sources and noise annoyance. J Acoust Soc Am 2004;116:949-57.
5. Miedema HM, Vos H. Noise annoyance from stationary sources: relationships with exposure metric day-eveningnight level (DENL) and their confidence intervals. J Acoust Soc Am 2004;116:334-43.

6. Niemann H, Maschke C. WHO LARES. Final report. Noise effects and morbidity [displayed 3 June 2009] Available at http://www.euro.who.int/Document/NOH/WHO Lares. pdf.

7. Ristovska G, Georgiev V, Gjorgjev D, Kocubovski M. Risk assessment of noise pollution in urban centre Skopje with digital modelling. J Environ Protect Ecol 2004;5:547-54.

8. Ristovska G, Gjorgjev D, Pop Jordanova N. Psychosocial effects of community noise: Cross sectional study of school children in urban centre of Skopje, Macedonia. Croat Med J 2004:45:473-6

9. International Organization for Standardization (ISO). ISO/ TS 15666:2003. Acoustics-Assessment of noise annoyance by means of social socio-acoustics surveys. Geneva: ISO; 2003.

10. Friis RH, Sellers T. Epidemiology for Public Health Practice. $3^{\text {rd }}$ ed. Boston (MA): Jones and Bartlett; 2004.

11. Directive 2002/49/EC of the European parliament and of the council of 25 June 2002 relating to the assessment and management of environmental noise [displayed 3 June 2009]. Avalialble at http://eur-lex.europa.eu/LexUriServ.do?uri=OJ: L:2002:189:0012:0025:EN:PDF

12. Babish W. Transportation noise and cardiovascular risk review and synthesis of epidemiological studies, dose-effect curve and risk estimation. WaBoLU-Hefte 01/06. Dessau: Umweltbundesamt; 2006.

13. Neus H, Eiff A-Wv, Rüddel H, Schulte W. Traffic noise and hypertension. The Bonn traffic noise study. In: Rossi G, editor. Proceedings of the $4^{\text {th }}$ International Congress on Noise as a Public Health Problem, Turin 1983. Milano: Edizioni Tecniche a cura del Centro Ricerche e Studi Amplifon; 1983. p. 693-8.

14. Björk J, Ardö J, Stroh E, Lövkvist H, Ostergren PO, Albin M. Road traffic noise in Southern Sweden and its relation to annoyance, disturbance of daily activities and health. Scand J Work Environ Health 2006;32:392-401.

15. Franssen EAM, van Dongen JEF, Ruysbroek JMH, Vos H, Stellato RK. Noise annoyance and perceived environmental quality, inventory 2003. Epidemiology 2005;16(5):S83.

16. Michaud DS, Keith SE, McMurchy D. Noise annoyance in Canada. Noise Health 2005;7:39-47.

17. Ohrstrom E. Longitudinal surveys on effects of changes in road traffic noise-annoyance, activity disturbances and psychosocial well-being. J Acoust Soc Am 2004;115:719-29. 


\section{Sažetak}

\section{UTJECAJ BUKE U OKOLIŠU NA UZRUJANOST ODRASLIH STANOVNIKA SKOPJA: PRESJEČNO ISTRAŽIVANJE}

Cilj ovog ispitivanja bio je utvrditi dnevne i noćne razine buke u Skopju te njihovu povezanost s osjećajem uzrujanosti u izloženoj populaciji. Provedena su mjerenja buke te razgovori s 510 odraslih ispitanika s pomoću upitnika sastavljenog prema normi ISO/TS-15666. Prosječna dnevna razina buke iznosila je $(62 \pm 6,45) \mathrm{dB}(\mathrm{A})$, a noćna $(56 \pm 6,52) \mathrm{dB}(\mathrm{A})$. Trinaest posto ispitanika iskazalo je izrazitu, a 33,5 \% umjerenu uzrujanost. Ispitanicima je najviše smetala buka s gradilišta (34 \%), prometna buka (24 \%) te buka proizišla iz aktivnosti u slobodnome vremenu (18 \%). Utvrdili smo statistički značajnu povezanost između dnevne izloženosti buci u rasponu od $61 \mathrm{~dB}(\mathrm{~A})$ do $65 \mathrm{~dB}(\mathrm{~A})$ i uzrujanosti (hi-kvadrat $=86,14 ; \mathrm{p}<0,001$ ) te statistički značajnu korelaciju $(R=0,45 ; p<0,05)$. Povezanost između izloženosti noćnoj buci i uzrujanosti utvrđena je već pri $46 \mathrm{~dB}(\mathrm{~A})$, a napose pri $>56 \mathrm{~dB}(\mathrm{~A})$, uz značajnu korelaciju $(\mathrm{R}=0,04$; $\mathrm{p}<0,05)$.

Razine uzrujanosti stanovnika Skopja zbog buke slične su onima u razvijenim europskim zemljama. Postoje međutim razlike u izvorima buke, koji su u našem ispitivanju ponajviše građevinske djelatnosti, cestovni promet te buka proizišla iz aktivnosti u slobodno vrijeme. Istraživanje je pokazalo da je procjena uzrujanosti stanovništva vrijedan podatak koji može poslužiti kod izrade urbanističkih planova i javnozdravstvene politike.

KLJUČNE RIJEČI: dnevna buka, izvori buke, javno zdravstvo, noćna buka, odraslo stanovništvo

\section{CORRESPONDING AUTHOR:}

Gordana Ristovska

Institute of Public Health

50 Divizija 6, Skopje, Macedonia

E-mail:drgordana@sonet.com.mk 